\title{
POBOLJŠANJE AKUSTIKE PROSTORIJA APSORPCIJSKIM MATERIJALIMA I ELEMENTIMA
}

\section{Željko Koški}

Sveučilište J. J. Strossmayera u Osijeku, Građevinski fakultet Osijek, pof.dr.sc.

\section{Mario Perak}

Sveučilište J. J. Strossmayera u Osijeku, Građevinski fakultet Osijek, student

Sažetak: U suvremenom životu čovjeka gotovo da nema trenutka u kojem zvuk ne ostvaruje neki oblik komunikacije s vanjskim svijetom. Napredak tehnike i tehnologije u arhitekturi stvorio je nove mogućnosti u građenju zgrada. Uporaba novih materijala omogućuje izvedbu bolje zaštite od buke koja je efikasnija nego prije. Istovremeno, različite funkcije zgrada postavljaju nove zahtjeve u postizanju kvalitetne akustike prostorija. Uz osnovne karakteristike fizikalne pojave zračnog zvuka, u članku se prezentiraju mogućnosti poboljšanja akustike prostorija. Analizirani su glavni elementi koji određuju akustičke karakteristike prostorija i primjena apsorpcijskih materijala i elemenata u funkciji poboljšanja akustike prostorija.

Ključne riječi: zvuk, akustika prostorija, apsorpcija zvuka, apsorpcijski materijali i elementi

\section{IMPROVEMENT OF ROOM ACOUSTIC WITH ABSORPTION MATERIALS AND ELEMENTS}

\begin{abstract}
In modern life there is almost no moment in which sound does not generate some form of communication with external world. Increase of engineering and technology in architecture creates new possibilities in building construction. Use of new materials provides more efficient implementation of noise protection than ever before. At the same time diverse functions of buildings lead to new requirement for quality acoustic. Apart from describing basic characteristics of physical manifestations of the flow of sound through air, in the article we present improvement possibilities for room acoustics. Analysed are basic factors which determinate acoustic characteristics of rooms, and usage of absorption materials and elements that can improve acoustic of rooms.
\end{abstract}

Key words: sound, acoustic of rooms, sound absorption, absorption materials and elements 


\section{Uvod}

Zvuk, kao fizikalna pojava titranja čestica u elastičnoj sredini, predstavlja uobičajeno sredstvo ljudske komunikacije. U suvremenom životu gotovo da nema trenutka u kojem zvuk možemo isključiti iz životnih funkcija. Stoga je jasna velika važnost koju zvuk ima za čovjeka. Gotovo sve pojave ili procesi u životnoj sredini stvaraju neki zvuk. Neke pojave stvaraju vrlo visoke razine zvuka, a druge jedva čujne. Neki uređaji pri radu proizvode jedva čujan zvuk, npr. kucanje sata, dok drugi pak veoma glasan, kao što su razne vrste motora, motorna vozila i slično.

Ubrzani razvitak industrije, tehnologije i prometa, unio je u čovjekov život vrlo moćne izvore zvuka. Naravno da ubrzani razvitak nije zaobišao ni građevinarstvo. Svjedoci smo novih načina građenja, ali i uvođenja uporabe novih građevinskih materijala. Osobit napredak se dogodio u području materijala s cementnim vezivom, među koje spadaju nove vrste betona i mortova. Također imamo i različite vrste opeke i druge sintetičke materijale i to sve u svrhu bržeg, jeftinijeg i kvalitetnijeg građenja. Uporaba tih modernih građevnih materijala ima i svoju lošu stranu, a to je da oni manje apsorbiraju zvuk od starijih, masivnijih materijala, čime se pojačava razina buke i ometanje ljudi za vrijeme boravka u zgradama. Kada govorimo o buci, zapravo govorimo o željenom ili neželjenom zvuku. Hoće li neki zvuk dobiti oznaku buke ne ovisi o apsolutnoj vrijednosti njegove razine, nego 0 činjenici ometa li on neku osobu ili ne. Tako, na primjer, zvuk vode koja kaplje iz slavine, iako je ekstremno niske razine, predstavlja buku ako nekoga ometa. Također za zvuk na rock koncertima ne možemo reći da je buka, iako je ekstremno visoke razine. Ova dva primjera najbolje prikazuju suštinu problema s kojima se susreće građevinska akustika koja treba osigurati da zvuk koji nastaje u zgradama nikoga ne ometa. Budući da je zaštitu od neželjenih zvukova u suvremenom životu sve teže postići, potrebno je poštivati propise o zaštiti od buke. Uz to, moguće je raznim mjerama u području građevinske akustike osigurati komfor i udobnost boravka čovjeka u zgradama.

Uz zaštitu od buke, osiguranje akustičke kvalitete prostorija važan je element svakog kvalitetnog procesa građenja. Koliki će biti značaj ove komponente određuje namjena zgrade, odnosno njezin unutrašnji sadržaj i okruženje u kojem se nalazi. U stambenim i poslovnim objektima, kao najraširenijem pojavnom obliku zgrada, akustička kvaliteta je regulirana zakonima. Boravak ljudi u zgradama određuje značaj akustičke komponente kvalitete zgrade. Ljudske aktivnosti definiraju uvjete koje treba zadovoljiti da bismo mogli govoriti o akustičkoj kvaliteti prostorija. U dijelovima zgrada u kojima nema dužeg boravka ljudi, akustička kvaliteta kao tema pri projektiranju i građenju zgrada se posebno ne razmatra.

U ovom članku prikazane su akustičke karakteristike materijala i elemenata u funkciji poboljšanja akustičke kvalitete prostorija u kojima boravi čovjek.

\section{Fizikalna svojstva zvuka}

Zvuk je titranje čestica u plinovitim, tekućim i krutim tvarima. Zvukom se u užem smislu naziva sve ono što čujemo, odnosno zamjećujemo sluhom. U plinovima i tekućinama valovi zvuka su isključivo longitudinalni, tj. šire se $u$ istom pravcu u kojem se gibaju čestice medija pri titranju, dok u čvrstim tijelima valovi mogu biti i transverzalni, tj. čestice medija mogu titrati i okomito na pravac širenja vala. Zvuk se ne može širiti kroz vakuum. Zvučni valovi se kroz različite medije kreću različitim brzinama. Brzina ovisi i o temperaturi medija kroz koji se zvuk kreće. U zraku se pri temperaturi od $20^{\circ} \mathrm{C}$ ti valovi kreću brzinom od $300 \mathrm{~m} / \mathrm{s}$, u vodi se kreću približnom brzinom od $1500 \mathrm{~m} / \mathrm{s}$, dok se u željeznoj žici kreću brzinom od $5000 \mathrm{~m} / \mathrm{s}$. Što je materijal gušći, zvuk se kroz njega prenosi duže i brže.

Visinu pojedinog zvuka određuje frekvencija zvučnog vala. Val ima svojstvo da se ciklički ponavlja u vremenu pa jedno takvo ponavljanje nazivamo valnim ciklusom. Frekvenciju vala možemo definirati kao broj ciklusa vala koji se ponavlja u jednoj sekundi. U slučaju našeg zvučnog vala, jedan ciklus traje onoliko koliko je potrebno da se tlak promijeni od najvećeg, preko najnižeg do ponovno najvećeg tlaka, a frekvencija označava koliko se takvih cikličkih promjena tlaka dogodi u jednoj sekundi. Mjerna jedinica za frekvenciju je $\mathrm{Hz}$ (Hertz), a oznaka je f. Frekvencija od $100 \mathrm{~Hz}$ označava učestalost, odnosno ponavljanje jednog valnog ciklusa 100 puta u sekundi. Povećanjem broja ciklusa u sekundi povećava se frekvencija zvuka, a takav zvuk registriramo kao viši. S druge strane, smanjenjem frekvencije zvuka dobivamo niže, odnosno dublje tonove. Prosječno ljudsko uho može 
čuti zvukove u frekvenciji od $16 \mathrm{~Hz}$ do $20000 \mathrm{~Hz}^{1}$. Sve frekvencije ispod $16 \mathrm{~Hz}$ nazivamo infrazvuk, a frekvencije više od $20000 \mathrm{~Hz}$ nazivamo ultrazvuk.

Važna karakteristika svakog vala, pa tako i zvučnog, jet njegova valna duljina. Kao što je kod vala na vodi valna duljina udaljenost između vrhova dvaju susjednih valova, tako je kod zvučnog vala valna duljina udaljenost između dva susjedna najveća zgušnjavanja, odnosno razrjeđenja. Naravno, valnu duljinu zvuka ne možemo vidjeti, ali je posebnim instrumentima možemo izmjeriti. Karakteristike frekvencije, valne duljine i brzine zvuka u međusobnom su odnosu, što znači da ako su nam poznate dvije od ove tri veličine, možemo izračunati i treću. Na putu što ga zvuk prevali u jednoj sekundi ima upravo toliko valova kolika mu je frekvencija. Prema tome, valna duljina $(\lambda)$ može se izračunati iz brzine širenja zvuka (c) i frekvencije (f) (1):

$$
\lambda=\frac{c}{f}[\mathrm{~m}]
$$

Čovjek kod zvuka uglavnom razlikuje visinu tona (frekvenciju) i njegovu jačinu (glasnoću). Budući da je ocjena jačine zvuka uhom subjektivna, u fizici je bilo potrebno uvesti objektivne mjere. U elastičnoj tvari zbog titranja čestica nastaje zvučni tlak kojeg mjerimo mikrobarima ili paskalima $(1 \mathrm{~b}=1 \mathrm{~Pa})$. Omjer zvučnih snaga proporcionalan je omjeru kvadrata pripadajućih zvučnih valova. Čujno područje zvučnog tlaka nalazi se između tzv. čujnog praga koji iznosi $2 \times 10^{-4}(0,2 \mathrm{~Pa})$ i praga boli koji iznosi $2 \times 10^{2}(20 \mathrm{~Pa})$. Iz toga zaključujemo da je omjer

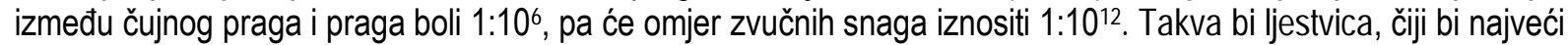
broj imao 12 nula, bila vrlo nepogodna pa se upotrebljava logaritamska ljestvica s bazom 10, za logaritme brojeva od 1 do 1012. Prema fizičaru Bellu, ljestvica je podijeljena na 12 dijelova, 12 B odnosno $120 \mathrm{~dB}$ (deciBella), $1 \mathrm{~dB}=$ 1/10 B. Decibel je jedinica bez dimenzije, a služi za iskazivanje omjera dvije istorodne veličine (zvučni tlak, zvučna snaga, zvučni intenzitet). S tako definiranom ljestvicom tihi zvukovi u životnoj sredini su reda veličine 20$30 \mathrm{~dB}$, normalan govor je nivoa 60-70 dB, a glasni zvukovi (npr. glasna glazba) ima razine 90-110 dB, pa i više.

\section{1 Širenje zvuka u otvorenom prostoru}

Da bismo objasnili zašto zvuk slabi s udaljenošću, možemo se poslužiti analogijom bacanja kamena u jezero. Najviši valovi, odnosno valovi najviše amplitude, pojavljuju se kada je kružni val u svom nastanku. Kako se val udaljava od svog izvora, tako su i njegovi koncentrični krugovi sve veći pa je i val u svojoj kružnoj dimenziji sve dulji. Kako ukupna energija vala po svom iznosu ostaje ista, ona se mora rasporediti unutar sve duljeg i duljeg vala, što znači da se iznos energije po jedinici duljine smanjuje. To za posljedicu ima smanjenje amplitude vala. Ista se događa i sa zvučnim valom koji se, emitiran iz svog izvora, širi kružno, jednako u svim smjerovima (slika 1). Kako se udaljava od izvora, gubi energiju po jedinici svoje dimenzije, odnosno pada mu amplituda, a upravo amplituda zvučnog vala određuje glasnoću zvuka - s padom amplitude, dok prelazi put, zvuk postaje sve tiši i tiši.

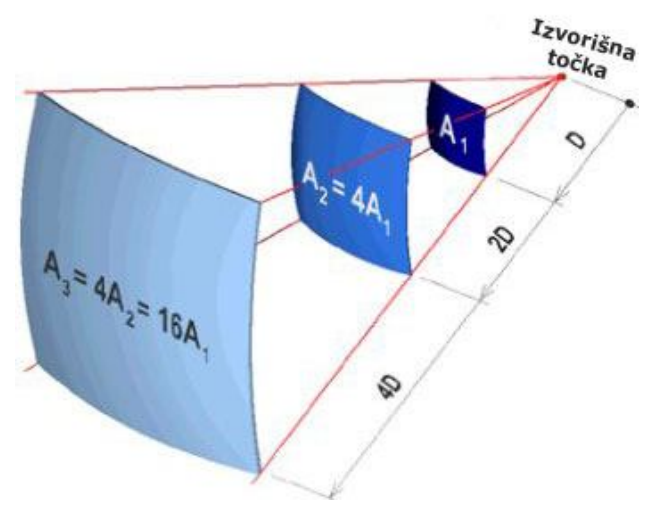

Slika 1 - Smanjenje razine zvuka povećanjem udaljenosti od izvora²

\footnotetext{
1 Šimetin, V.: Građevinska fizika, GI Fakultet građevinskih znanosti Sveučilišta u Zagrebu, Zagreb1983. str.134.

2 Širenje zvuka u otvorenom prostoru. Dostupno na: http://www.isover.hr/ltem.aspx?ld=21
} 
Za zvuk možemo reći da ima dva značenja: subjektivno ili psihološko i objektivno ili fizikalno. U prvom smislu zvuk je vezan za slušni osjet, a u drugome to je energija koja se širi i onda kada nema uha koje bi je otkrilo. Za nas je važno ovo prvo značenje, jer se u građevinskoj akustici razmatraju zvučne pojave koje čuje normalno uho, a i konačan sud o akustičkoj kvaliteti neke prostorije donosi se na temelju slušanja.

\section{2 Širenje zvuka u zatvorenom prostoru}

U zatvorenom prostoru zvučni val udara u površinu konstrukcije građevine prije nego znatno oslabi. Zvučno polje u zatvorenom prostoru nije sferno, ali ovisi o geometriji i akustičkim svojstvima tih površina. Zapremina prostorije i udaljenosti između izvora zvuka, površine konstrukcija građevine i mjesta slušanja također su važni. Zvuk se na određenom mjestu slušanja u prostoriji sastoji od direktnog i reflektiranog zvuka. Direktan zvuk jest zvuk koji se još nije odbio od neke površine. Zbroj svih reflektiranih zvukova zove se reverberacijsko zvučno polje. Sastoji se od svih zvukova koji su se odbili jedanput, dvaput ili više puta od površina konstrukcije građevine. Zvuk koji je reflektiran jednom zove se prva refleksija, dvaput druga refleksija itd.

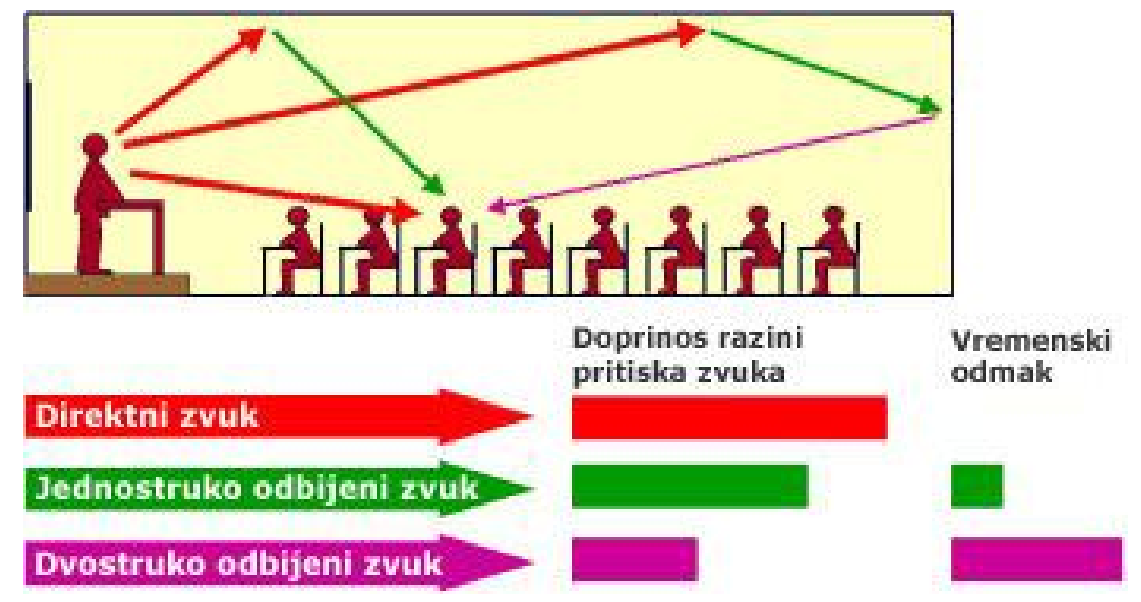

\section{Slika 2 - Širenje zvučnih valova u zatvorenom prostoru³}

Velik dio energije zvučnog vala reflektira se kad udari o površinu tvrdog građevnog materijala. Kut upada 'a' jednak je kutu refleksije 'b' za ravne površine. Ako se površina ne može smatrati ravnom, refleksija će biti difuzna.

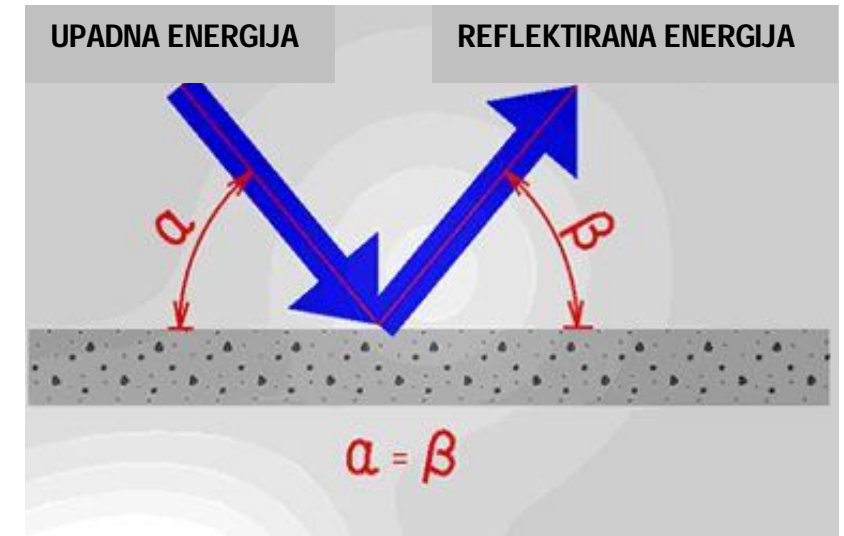

Slika 3 - Refleksija zvuka od glatke površine građevinskog elementa ${ }^{4}$

\footnotetext{
${ }^{3}$ Širenje zvuka u zatvorenom prostoru. Dostupno na: http://www.isover.hr/ltem.aspx?ld=21

${ }^{4}$ Kriteriji apsorpcije zvuka. Dostupno na: http://www.isover.hr/ltem.aspx?ld=43
} 
Općenito, refleksija nikad nije potpuna kao što je prikazano na slici 3, čak i kod vrlo tvrdih građevnih materijala. Betonski zid, primjerice, tipično ima koeficijent apsorpcije 1\% pri niskim frekvencijama, te $3 \%$ pri visokim frekvencijama.Refleksija zvučnog vala, kad on udari u materijal, događa se zbog posebnog akustičkog svojstva koje se može nazvati akustički otpor (akustička impedancija). Svi materijali imaju vlastiti akustički otpor, od vrlo malog kod zraka, do vrlo visokog kod, na primjer, betona ili stakla.

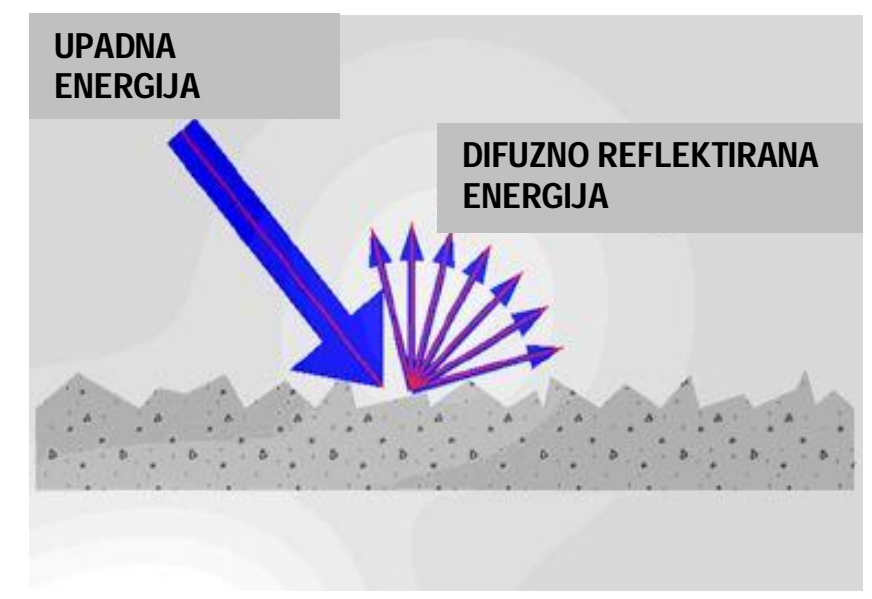

\section{Slika 4 - Refleksija zvuka od difuzne površine građevinskog elementa ${ }^{5}$}

Difuzne površine koriste se da bi se izbjegla jeka i koncentracija zvuka. Difuzija je također važna i na suptilniji način, primjerice u prostorijama uređenima za glazbu. Postoje mnogi načini konstruiranja difuzne površine. Zid ili strop može se opremiti nagnutim, zakrivljenim ili pomaknutim panelima. Dimenzije difuznih panela moraju se usporediti s valnom dužinom zvuka koji treba raspršiti. Jedno od osnovnih pravila jest da izbočine moraju doseći najmanje jednu sedminu valne dužine zvuka.

Koeficijent apsorpcije ovisi o kutu upada zvučnog vala. Ta se poteškoća otklanja time što se računa sa "statičkim" koeficijentom apsorpcije koji vrijedi kao srednja vrijednost za statički raspodijeljene kutove upada. Time koeficijent apsorpcije postaje konstanta određenoga akustičkog materijala.

\section{Akustička kvaliteta prostorija}

Znanost 0 akustici prostorija relativno je mlada. U proteklih nekoliko desetaka godina zanimanje za akustiku prostorija uvelike je poraslo. Akustička kvaliteta koja se dobiva prijenosom preko komunikacijskih medija kao što su radio, televizija, telefonija itd., uvelike ovisi o akustičkim osobinama prostorija iz kojih se prenosi. Također, danas su akustički principi sve važniji i pri projektiranju predavaonica, uredskih prostorija, bolnica, hotela itd. Tome je jedan od razloga uporaba modernih građevnih materijala koji manje apsorbiraju zvuk nego stari materijali. Zato je odjek često suviše velik, čime se pojačavaju buka i smetnje. Zadatak građevinske akustike je u prostorijama stvoriti uvjete za dobro i ugodno slušanje. Pritom trebaju biti zadovoljni ne samo slušač, nego i govornik. Da bismo dobili dobru akustiku u prostoriji, potrebno je zadovoljiti sljedeće uvjete ${ }^{6}$.

1. u prostoriji ne smije biti buke, niti unutarnje niti vanjske

2. zvuk u prostoriji mora biti dovoljno glasan na svim mjestima

3. u prostoriji ne smije biti jeke

4. glasnoća zvuka mora biti približno posvuda jednaka, što znači da na mjestima udaljenijim od izvora zvuka, izvornom zvuku treba dodati reflektirani zvuk od prikladno postavljenih ploha u prostoriji

5. u prostoriji ne smiju nastati neželjene rezonancije

6. odjek mora biti dovoljno malen da bi se izbjegla preklapanja uzastopnih zvukova u govoru i glazbi, zbog toga direktan zvuk mora biti u određenom odnosu prema reflektiranom.

\footnotetext{
${ }^{5}$ Kriteriji apsorpcije zvuka. Dostupno na: http://www.isover.hr/ltem.aspx?ld=43

6 Jelaković T.: Zvuk, sluh, arhitektonska akustika. Školska knjiga, Zagreb, 1978. str. 93.
} 
Teorijska razmatranja i mjerenja u izvedenim prostorijama pokazala su da optimalna duljina odjeka ovisi o veličini prostorije, ali i o tome za koje svrhe se ona upotrebljava. Također je važan i oblik prostorije, jer utječe na raspodjelu zvuka. Tako dolazimo do tri važna čimbenika koji određuju akustičke osobine prostorije, a to su volumen, oblik i odjek (reverberacija) 7 .

\subsection{Volumen prostorije}

Svakom izvoru zvuka odgovara određeni volumen prostorije do kojeg se može ići, a da pritom glasnoća ne postane premalena. Povećavamo li volumen prostorije, raste i unutarnja površina te prostorije pa je samim time i apsorpcija zvuka veća. Iz toga možemo zaključiti da uz jednaku emitiranu zvučnu energiju, imamo manju glasnoću.

Tablica 1 - Orijentacijske vrijednosti volumena za neke izvore zvuka

\begin{tabular}{|c|c|}
\hline Izvor zvuka & Maksimalni volumen dvorane u $\mathrm{m}^{3}$ \\
\hline Prosječan govornik & 3000 \\
Uvježban govornik & 6000 \\
Instrumentalni ili vokalni solist & 10000 \\
Simfonijski orkestar & 20000 \\
\hline
\end{tabular}

Osnova po kojoj se određuje volumen koncertnih dvorana jest volumen po slušatelju. Minimalni specifični volumen po slušatelju je $6,5 \mathrm{~m}^{3}$ ispod kojega se ne bi smjelo ići ako se želi postići akustička kvaliteta. Optimalan specifični volumen bi bio između $7-8 \mathrm{~m}^{3}$ po osobi. Ako bi se išlo na veće volumene, bilo bi problema s odjekom pa bi se morala dodavati apsorpcijska sredstva. Dijagram na slici 5. prikazuje ovisnost specifičnog volumena o broju slušatelja za razne vrste glazbe. Iz dijagrama se može primijetiti da je veće vrijednosti od gore spomenutih, no on vrijedi ako je apsorpcija prostorije jednaka apsorpciij prisutnih slušatelja.

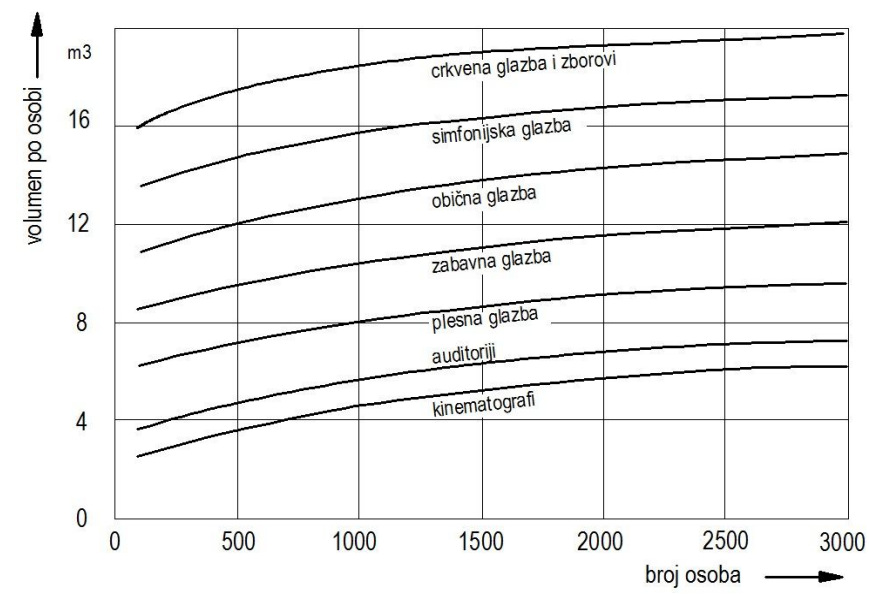

\section{Slika 5 - Najmanji volumen prostorija ovisno o broju osoba za različite vrste glazbe ${ }^{8}$}

Optimalan volumen za koncertnu dvoranu bi bio između 10000 i $15000 \mathrm{~m}^{3}$. Dobri se rezultati mogu postići i uz manje volumene, od 6000 do $7000 \mathrm{~m}^{3}$. Nije preporučljivo ići na veće volumene, jer tada može doći do teškoća prilikom solističkih izvedaba. Na osnovi ovih predočenih podataka proizlazi da koncertna dvorana optimalnih akustičkih svojstava može primiti 1600 - 1700 slušatelja.

Za kino-dvorane volumen po sjedalu kreće se između 3 i $4 \mathrm{~m}^{3}$. Zbog tako malog volumena po osobi potrebno je osigurati dobru ventilaciju. Veći volumen bio bi štetan iz dva razloga. Prvo, većim volumenom strop bi bio viši pa bi zbog toga bio slabije iskorišten kao reflektor zvuka i drugo, odjek bi bio vrlo velik. Za predavaonice se uzima kao optimalan volumen $4-5 \mathrm{~m}^{3}$ po sjedalu, odnosno osobi.

7 Jelaković T.: Zvuk, sluh, arhitektonska akustika. Školska knjiga, Zagreb, 1978. str. 94.

8 Jelaković T.: Zvuk, sluh, arhitektonska akustika. Školska knjiga, Zagreb, 1978. str. 95. 


\subsection{Oblik prostorije}

Jedan od najvažnijih čimbenika o kojemu ovise akustička svojstva prostorije jest njezin oblik. Zbog toga je vrlo važno već u procesu projektiranja svim prostorijama i unutarnjim plohama odrediti ispravan oblik i položaj. U suprotnom, ako se o ovome ne vodi računa, u objektu se mogu pojaviti akustički nedostatci koje je kasnije gotovo nemoguće ukloniti. Prilikom akustičkog projektiranja, pažnju je potrebno posvetiti svim plohama prostorije. To se odnosi na pod i strop, na bočne strane, prednju i stražnju stranu te strop ispod balkona.

Kada govorimo o raspodjeli zvuka u prostoriji, važno je znati da zvuk dolazi do slušatelja što kraćim putem. Prema tome, prostorija tlocrtnog oblika kao na slici 6 povoljna je oblika, jer su zvučne zrake od govornika pa do najudaljenijeg slušatelja gotovo jednake. No ipak, ta prostorija nije akustički ispravna. Da bi slušatelji mogli govornika dobro čuti, moraju se nalaziti unutar kuta od $\pm 45^{\circ}$ ispred govornika. Kao što se vidi na slici, veliki dio prostorije ostaje izvan toga kuta pa prema tome ta prostorija akustički ne odgovara. Iz akustičkog aspekta bolja je prostorija s tlocrtom na slici 7.

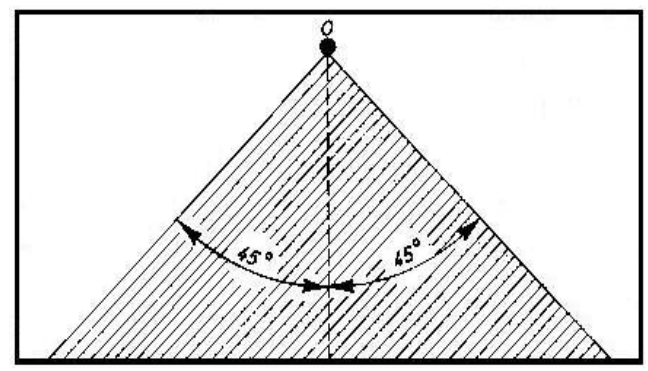

Slika 6 - Neispravno smještanje izvora zvuka ${ }^{9}$

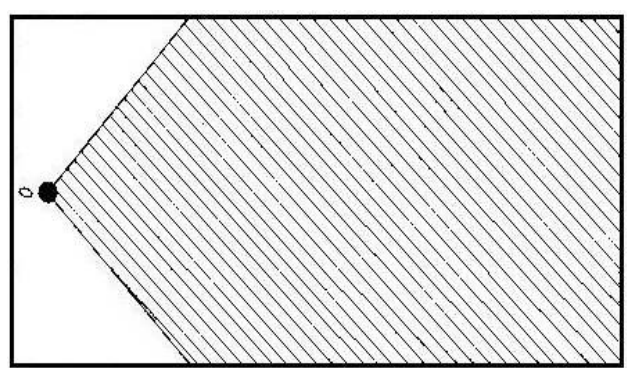

Slika 7 - Ispravno smještanje izvora zvuka

Iz akustičkog aspekta vrlo su povoljne prostorije trapezna ili lepezasta oblika, jer tada imamo usmjereni kut i kratak razmak između govornika i slušatelja (slika 8). Tada bočne stijene prostorije postaju dobar reflektor koji ravnomjerno reflektira zvuk po cijelom auditoriju.
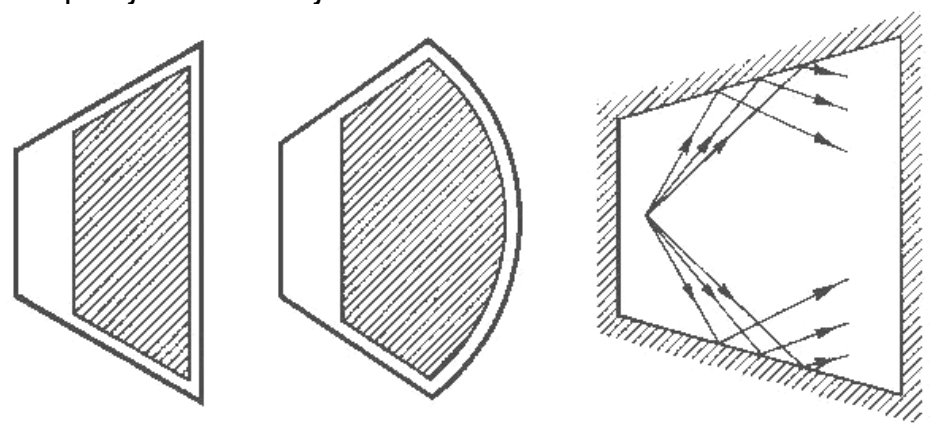

Slika 8 - Za auditorije vrlo je povoljan lepezast tlocrt dvorane

Kod većih dvorana, gdje imamo veliki broj sjedala, zvuk prilično oslabi prolazeći preko glava i tijela slušatelja pa se onda javlja problem da na stražnjim sjedalima glasnoća nije dovoljna. To se može riješiti izdizanjem izvora zvuka do one ravnine na kojoj će se izravnom zvuku osigurati slobodan put do stražnjih sjedala dvorane.

${ }^{9}$ Slike: 6, 7, 8 - Izvor: Jelaković T.: Zvuk, sluh, arhitektonska akustika. Školska knjiga, Zagreb, 1978. str. 101 - 102. 
Potrebnu visinu izdizanja zvuka možemo izračunati po formuli10 (2):

$$
H=h \cdot \frac{S-r}{r}[\mathrm{~m}]
$$

$$
\begin{aligned}
& S=\text { udaljenost posljednjeg sjedala od izvora } \\
& H=\text { visina izvora iznad glava } \\
& r=\text { razmak između redova } \\
& h=\text { visina glave slušatelja u posljednjem redu }
\end{aligned}
$$

Da slušanje bude dobro, $h$ mora iznositi barem $12 \mathrm{~cm}$. Moglo bi se ići i do $8 \mathrm{~cm}$, no tada bi se moralo susjedne redove međusobno pomaknuti u bočnom smjeru za pola sjedala. Za normalnu visinu glave od poda uzima se $1,2 \mathrm{~m}$, a za razmak između redova $0,85 \mathrm{~m}$. Ako je broj redova auditorija velik, ne može se izvesti ravan pod, jer bi tada izvor zvuka trebalo suviše izdignuti iznad glava slušatelja u prvim redovima. Tada se prednji redovi postave na ravnom podu, a ostali na uzdignutom dijelu (slika 9). To omogućuje slušanje izravnog zvuka i u stražnjem dijelu dvorane.

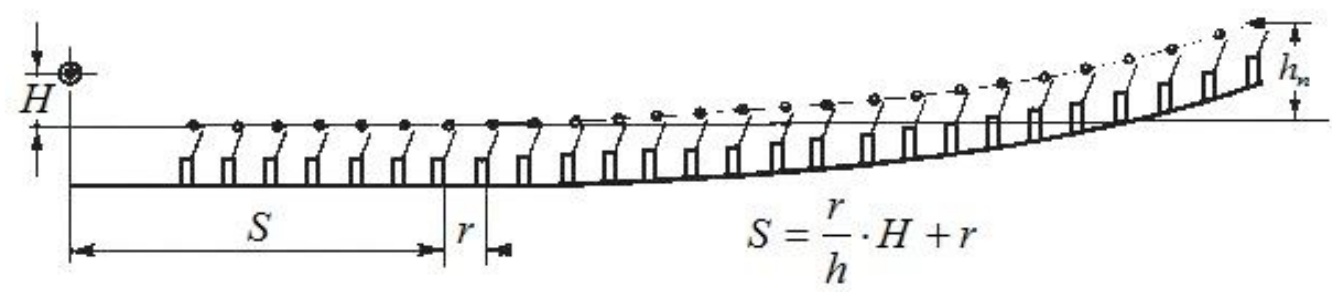

\section{Slika 9 - Postupno izdignuta stražnja sjedala u dvorani11}

Na slici 10 imamo primjer oblika poda koji u prednjem dijelu nije vodoravan, već uzdignut. Ovime se postiže manje izdizanje stražnjeg dijela i dobra akustička veza između izvora zvuka i slušatelja, a da pritom izdizanje nije veliko. Ovakav profil poda najčešće se upotrebljava u kino dvoranama.

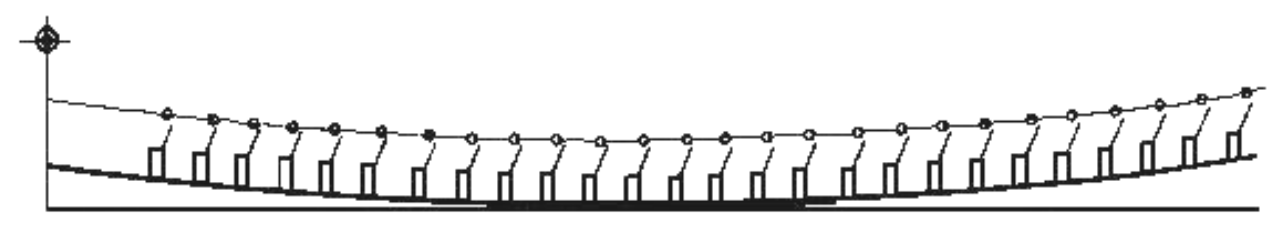

\section{Slika 10 - Izdignuta prednja i stražnja sjedala u dvorani}

\subsection{Reverberacija ili odjek}

Ako se nalazimo u dugačkim hodnicima ili velikim halama, možemo čuti zvuk i poslije prestanka emisije zvučnog izvora. Uzrok ovomu su višestruke refleksije koje daju utisak da zvuk traje dosta dugo. Ova pojava je poznata kao odjek ili reverberacija. Za vrijeme svake refleksije, dio zvučne energije je apsorbiran pa će poslije izvjesnog vremena zvuk prestati. Vrijeme reverberacije definira se kao vrijeme koje je potrebno da se razina zvuka smanji za $60 \mathrm{~dB}$ nakon što je izvor zvuka isključen (slika 11).

\footnotetext{
10 Jelaković T.: Zvuk, sluh, arhitektonska akustika. Školska knjiga, Zagreb, 1978. str. 104.

11 Slike 9, 10 - Izvor: Jelaković T.: Zvuk, sluh, arhitektonska akustika. Školska knjiga, Zagreb, 1978. str. 104.
} 


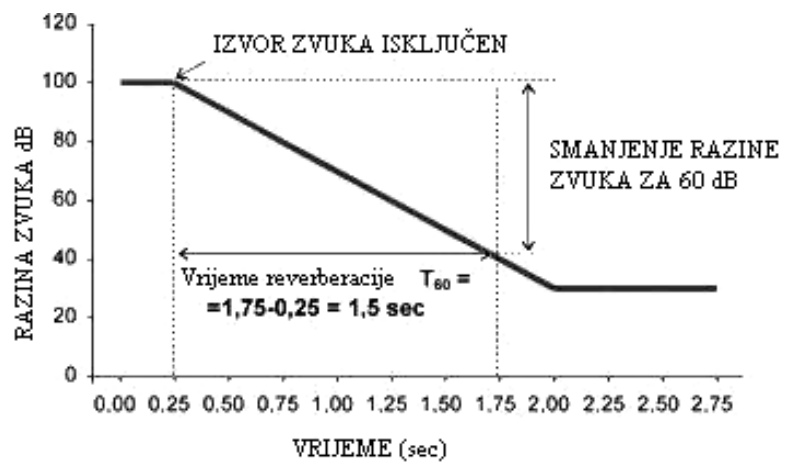

\section{Slika 11 - Grafički prikaz određivanja vremena reverberacije ${ }^{12}$}

Temelje akustici prostorija i proučavanju reverberacije postavio je američki fizičar W. C. Sabine. On je još davne 1895. godine započeo svoja istraživanja na Harvardskom sveučilištu gdje je pokušao popraviti vrlo lošu akustiku u velikoj sveučilišnoj predavaonici. Nakon niza eksperimenata, Sabine je zaključio da je uzrok loše akustike dugotrajno prigušivanje zvučne energije, što se događa tek nakon mnogo refleksija i pri čemu se svaki puta dio energije apsorbira. Drugim riječima, nerazumljivost govora posljedica je predugog odjeka. Služeći se sredstvima koja su mu u ono vrijeme bila dostupna te vlastitim sluhom, Sabine je, na osnovi svojih mjerenja, uspio izvesti formulu za izračunavanje vremena reverberacije ${ }^{13}$ (3) koja i danas vrijedi:

$$
T=\frac{0,161 \cdot V}{A}[\mathrm{~s}]
$$

T je vrijeme u sekundama, A je ukupna apsorpcijska površina prostorije izražena u kvadratnim metrima, dok je $\mathrm{V}$ volumen prostorije.

Prevelika reverberacija uzrokuje da nam izgovorene riječi zvuče neobično, a za slušatelja na malo većoj udaljenosti i nerazgovjetno. S druge strane, premala reverberacija uzrokuje da je zvuk „tup“ i prigušen. Za velike koncertne dvorane, kino dvorane, ali i za obične prostorije potrebno je prilagoditi željenu vrijednost reverberacije zbog ugodnog boravka i slušanja glazbe. Za čovjeka je najpogodnije vrijeme reverberacije u namještenim sobama između 0,7 i $1,5 \mathrm{~s}$. U velikim prostorijama, dvoranama, velika reverberacija izaziva nerazumljivost govora, lošu reprodukciju glazbe itd. Ona se smanjuje presvlačenjem zidova rupičastim drvenim ili sličnim pločama. Zbog potrebe za uobičajenom reverberacijom, koncertne, operne i baletne probe se izvode redovito pred punom dvoranom, jer se jedino tako može ocijeniti je li glazbena proba postigla određenu kvalitetu.

Često se u praksi u koncertnim dvoranama postavljaju reflektori. Njihova uloga je sprječavanje efekta prve refleksije. Vrijeme između kojeg do slušatelja dođe direktan zvuk i prvi reflektirani zvuk stvara utisak izoliranosti. Zato se reflektori postavljaju da stvore raniji prvi reflektiran zvuk i umanje opću reverberaciju.

\section{Apsorpcijski materijali i elementi}

Sve plohe, svi materijali i predmeti u nekoj prostoriji apsorbiraju zvuk. Kad se govori o apsorpcijskim materijalima ili 0 apsorpcijskim konstrukcijama, misli se na one kojima je osnovni zadatak da svojim akustičkim svojstvima proizvedu kontroliranu apsorpciju. Svrha je takvih akustičkih materijala i elemenata u praksi da: (1) skrate vrijeme odjeka, (2) otklone pojavu jeke i (3) priguše buku.

Zvuk se u nekom materijalu apsorbira na taj način što se pretvori u drugi oblik energije i, konačno, u toplinu. Kad zvučni val udari u neku plohu, jedan se dio zvučne energije reflektira, a ostatak se apsorbira i propusti (slika 12). Pod koeficijentom refleksije $r$ razumijeva se odnos amplitude tlaka reflektiranog vala prema amplitudi tlaka upadnog vala. Koeficijent apsorpcije $\alpha$ definiran je odnosom apsorbirane prema upadnoj zvučnoj energiji (4).

\footnotetext{
12 Akustički kriteriji prostorije. Dostupno na: http://www.isover.hr/ltem.aspx?ld=42

13 Jelaković T.: Zvuk, sluh, arhitektonska akustika. Školska knjiga, Zagreb, 1978. str. 123.
} 
Kako je zvučna energija razmjerna kvadratu amplitude tlaka, za koeficijent apsorpcije vrijedi:

$$
\alpha=1-r^{2}[\%]
$$

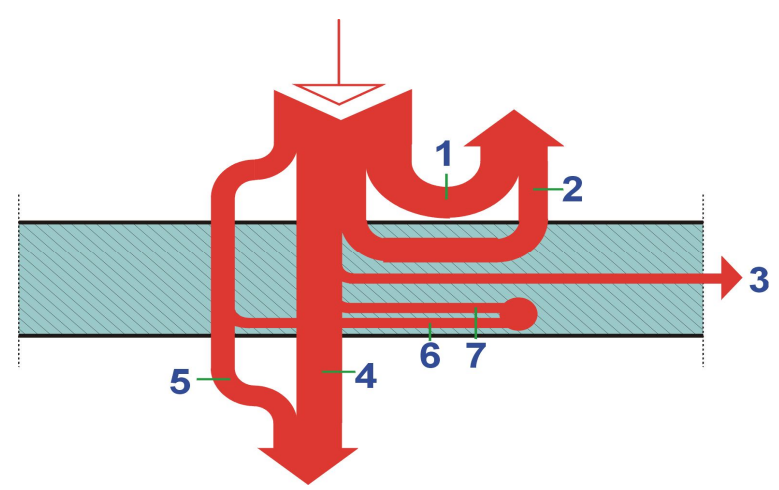

1-dio energije zvučnog vala koji se reflektira natrag u prostoriju

2-dio energije vibriranja pregrade vraća se natrag u istu prostoriju

3-manji dio širi se uzduž pregrade

4-preostalu energiju zrači pregradna stijena u prijemnu prostoriju

5-ako je element porozan, dio zvučne energije prelazi u prijemnu prostoriju zračnim putem kroz pore

\section{Slika 12 - Raspodjela energije zvučnog vala koji udari u građevinski element14}

Akustičke osobine apsorpcijskih materijala mogu se opisati i akustičkom impedancijom. Ona je definirana kompleksnim odnosom zvučnog tlaka i odgovarajuće titrajne brzine čestica na površini materijala. No matematička obrada problema u akustici prostorija uz pomoć akustičke impedancije vrlo je složena pa za normalnu praksu nije prihvatljiva.

U praktičnoj graditeljskoj akustici susreću se tri vrste apsorpcijskih materijala i elemenata15:

1. porozni

2. membranski

3. rezonatorski.

\subsection{Porozni materijali}

Tipični porozni apsorpcijski materijali su tekstilni produkti od vune, pamuka i svile, izrađevine od biljnih niti (koks, juta i dr.), mineralna vuna, strugotine od drveta, staklena vuna itd. U njima se zvuk apsorbira na taj način što on potakne zrak u porama na titranje pa se trenjem zraka o stjenke pora zvučna energija „poništava“, tj. pretvara u toplinu. Ona se u porama troši i zbog razmjene topline stijenki materijala i ugrijanog komprimiranog ili ohlađenoga razrijeđenog zraka.

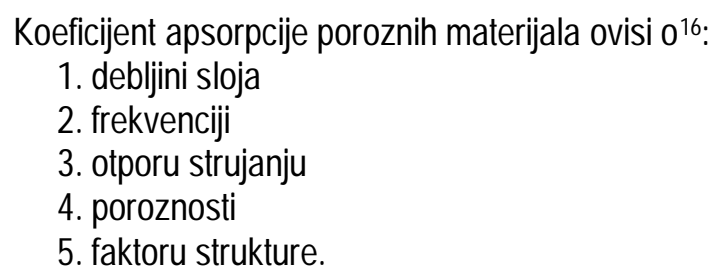

U debljemu poroznom sloju (slika 13) apsorbira se cijela zvučna energija koja prodre u sloj te se pretvara u toplinu, pa je koeficijent određen samo reflektiranim dijelom. Ako je sloj tanak (slika 14), jedan se dio zvučne energije, koji prođe kroz sloj, reflektira od tvrde stijene pa je koeficijent apsorpcije manji.

\footnotetext{
${ }^{14}$ Šimetin, V.: Građevinska fizika, GI Fakultet građevinskih znanosti Sveučilišta u Zagrebu, Zagreb1983. str. 190.

15 Jelaković T.: Zvuk, sluh, arhitektonska akustika. Školska knjiga, Zagreb, 1978. str. 180.

${ }^{16}$ Jelaković T.: Zvuk, sluh, arhitektonska akustika. Školska knjiga, Zagreb, 1978. str. 181.
} 


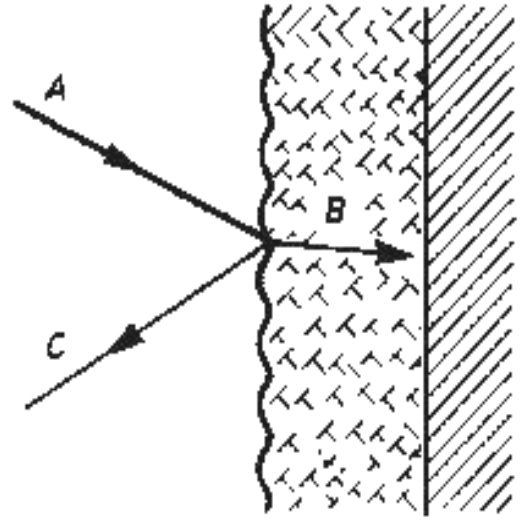

Slika 13 - Apsorpcija zvuka u debelom sloju poroznog apsorbera ${ }^{17}$

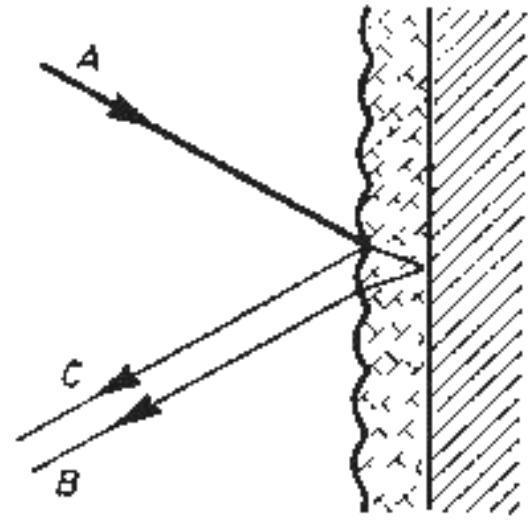

Slika 14 - Apsorpcija zvuka u tankom poroznom sloju

Koeficijent apsorpcije poroznih materijala ovisan je o otporu strujanju. Tako se maksimalni koeficijent apsorpcije od 0,8 dobiva pri otporu strujanju od $10^{4} \mathrm{~m}^{-3} \mathrm{~kg} \mathrm{~s}^{-1}$. Takav otpor strujanju ima vrlo rastresit sloj od vlakanaca. Koeficijent apsorpcije tvrdo tlačene ploče od drvenih vlakanaca $1 \mathrm{~cm}$ debele, najveći je pri otporu strujanju od $10^{6} \mathrm{~m}^{-3} \mathrm{~kg} \mathrm{~s}^{-1}$ i iznosi manje od 0,1.

Sagovi su tipični materijali s velikom apsorpcijom u području srednjih i visokih frekvencija. Najčešće im je otpor strujanju optimalan, tako da imaju maksimalan koeficijent apsorpcije.

Kao što smo napomenuli prije, koeficijent apsorpcije dosta ovisi i o poroznosti materijala. Poroznost je definirana odnosom volumena zraka u porama i ukupnog volumena. Ta dva čimbenika, otpor strujanju i poroznost, nisu dovoljna da se karakterizira neki porozni materijal. Kanali u materijalu mogu teći u raznim smjerovima i mogu završavati slijepo, a to nije obuhvaćeno ni poroznošću ni otporom strujanju. Te geometrijske osobine materijala utječu na višim frekvencijama, što se u račun unosi faktorom strukture. Tek uvođenjem tog faktora bilo je moguće objasniti veliko apsorpcijsko djelovanje tzv. akustik-ploča. Ploče imaju rupe promjera većeg od 4mm, razmak između nijh oko $15 \mathrm{~mm}$, tako da na kvadratni metar dolazi više od 4000 rupa (slika 15). Akustik-ploče najrašireniji su akustički materijal, a upotrebljavaju se u školama, bolnicama, uredima, hotelima, svugdje gdje je potrebno prigušiti buku i smanjiti odjek.
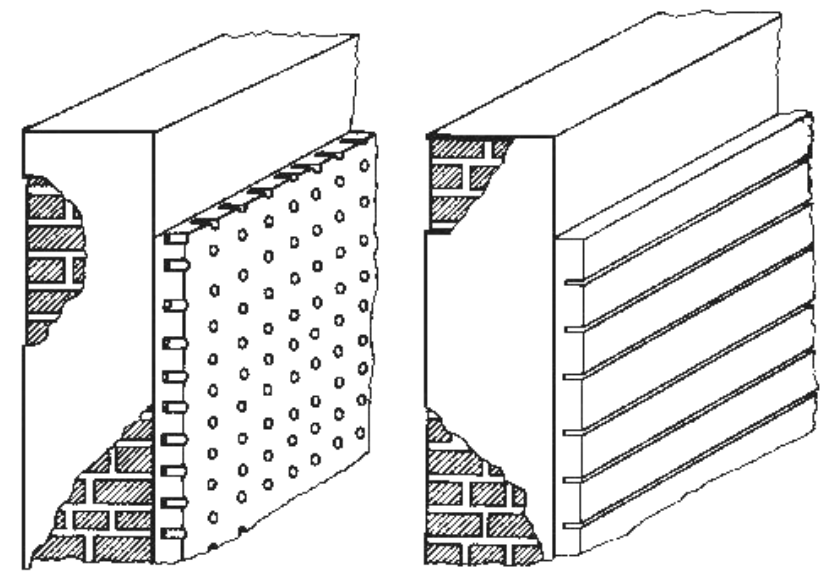

Slika 15 - Akustik-ploče: lijevo s okruglim rupama, desno s urezanim brazdama ${ }^{18}$

\footnotetext{
17 Slike 13, 14 - Izvor: Jelaković T.: Zvuk, sluh, arhitektonska akustika. Školska knjiga, Zagreb, 1978. str. 181.
}

18 Jelaković T.: Zvuk, sluh, arhitektonska akustika. Školska knjiga, Zagreb, 1978. str. 184. 


\subsection{Membranski apsorberi}

U praksi se membranski apsorberi izvode kako je prikazano na slici 16. Preko rešetke od letava pričvrsti se tanka ploča ili membrana od drveta, ljepenke, kože uljnog platna i sl. Apsorpcija nastaje tako da dio ploče koji pokriva pojedino polje rešetke pod djelovanjem zvučnih valova titra, na što se troši energija zvuka. Ploča može titrati na više načina (slika 16). Najveća apsorpcija nastaje na osnovnoj rezonantnoj frekvenciji.

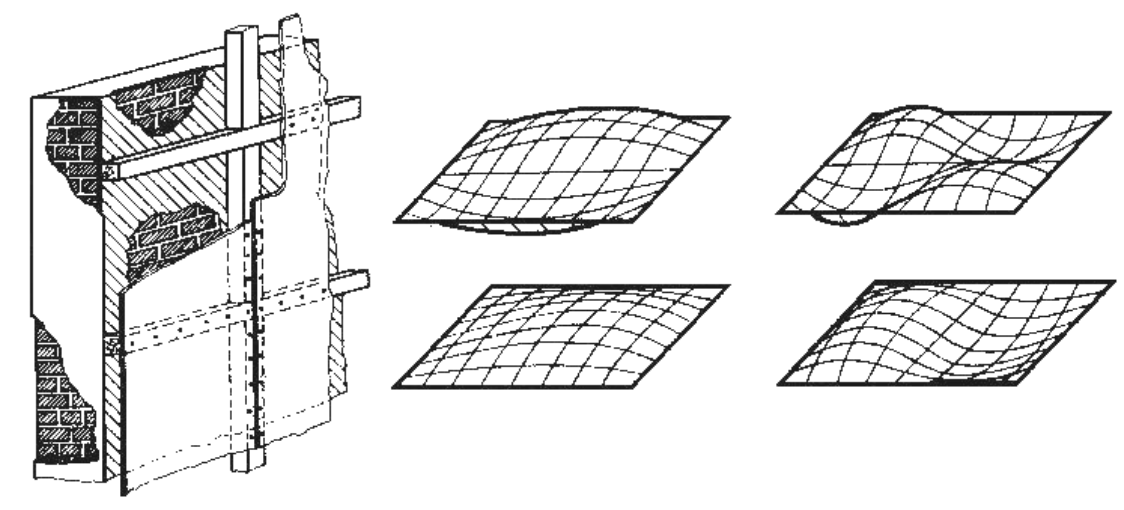

\section{Slika 16 - Primjer konstrukcije membranskog apsorbera i nekoliko načina titranja ploče ${ }^{19}$}

Koeficijent apsorpcije membranskih apsorbera može se znatno povećati stave li se porozni apsorpcijski materijali u prostor zračnog jastuka. Pritom nije potrebno ispuniti cijeli prostor, dovoljno je da se materijal stavi samo uz okvir. Mijenjanjem debljine ploče, debljine zračnog jastuka i načinom akustičke obrade prostora iza ploče, može se znatno utjecati na vrijednost koeficijenta apsorpcije zvuka.

U građevinama i unutrašnjoj opremi prostorija ima mnoštvo nehotičnih membranskih apsorbera. Obješeni strop od gipsa, drvene obloge ili drveno opločenje, ormari, prozori, vrata itd., sve su to apsorberi koji povoljno djeluju na niskim frekvencijama jer smanjuju vrijeme odjeka. Poznat je neugodan osjećaj u podrumima, kupaonicama i sličnim prostorijama gdje apsorbera membranskog tipa nema, pa je vrijeme odjeka u niskom frekvencijskom području vrlo dugo.

\subsection{Rezonatorski apsorberi}

Za rezonatorske apsorbere upotrebljavaju se akustički rezonatori. To su kutije ili posude s otvorom kojima zrak u otvoru, grlu, predstavlja masu koja pod djelovanjem zvučnog tlaka titra, a volumen zraka u samoj kutiji ili posudi, služi kao opruga (slika 17).
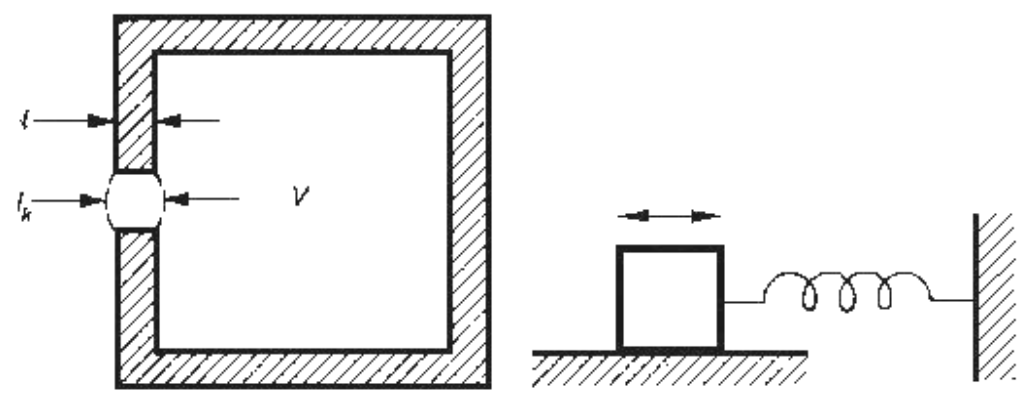

Slika 17 - Akustički rezonator i analogni mehanički rezonator ${ }^{20}$

\footnotetext{
19 Jelaković T.: Zvuk, sluh, arhitektonska akustika. Školska knjiga, Zagreb, 1978. str. 189.

20 Slike 17, 18 - Izvor: Jelaković T.: Zvuk, sluh, arhitektonska akustika. Školska knjiga, Zagreb, 1978. str. 192 - 193.
} 
Prigušivanje će nastati dijelom zbog reradijacije zvučne energije, djelomično zbog trenja čestica zraka i stijenke grla, ali će utjecati i umjetno prigušenje koje se poduzima da bi se dobila željena vrijednost. Hotimično prigušivanje postiže se stavljajući porozan materijal u kutiju ili stavljajući mrežast materijal preko grla.

Akustički se rezonatori upotrebljavaju bilo kao pojedinačni rezonatori, razmješteni daleko jedan od drugoga da ne bi međusobno djelovali, bilo kao spojeni rezonatorski sistemi (panelni rezonatori), ili, konačno, kao rezonatori s rasporom, tj. takvi kojima je jedna dimenzija mnogo veća od valne duljine na rezonantnoj frekvenciji.

Pojedinačni rezonatori moraju biti izrađeni od čvrsta materijala, npr. betona, kako bi prilikom titranja gubitci u stijenama bili što manji. Da se dobije velika apsorpcija, otpor trenja treba biti malen. Obično se ovim rezonatorima u kutiju ne stavlja ni porozni materijal ni mrežasti materijal preko grla.

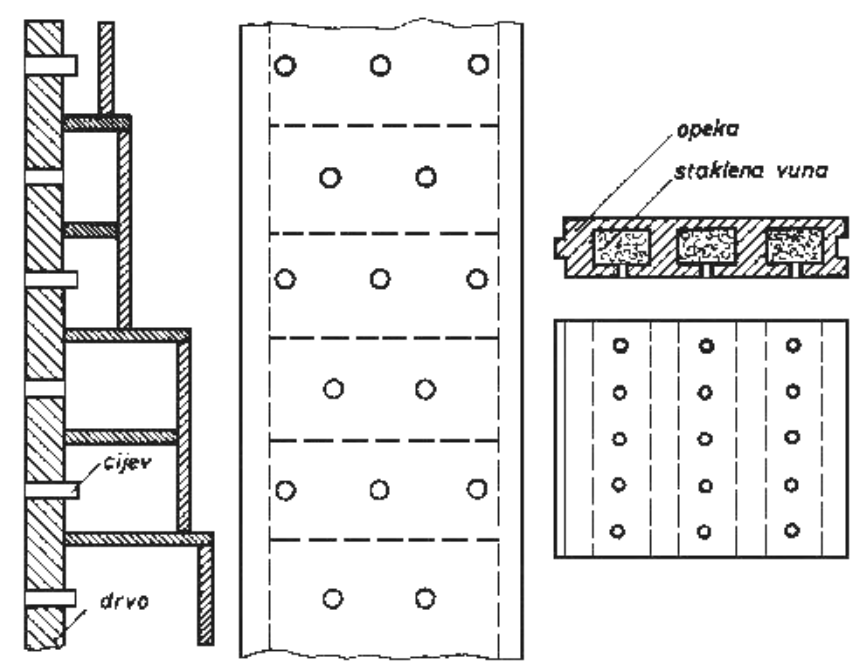

\section{Slika 18 - Primjeri izvedbi pojedinačnih rezonatora}

O zanimljivoj uporabi rezonatora piše Vitruvius u knjizi De Architectura. U starim grčkim i rimskim kazalištima bile su ispod sjedala smještene vaze od bronce otvorima okrenute prema orkestru. Vaze su bile ugođene na tonove glazbala. Prema Vitruviusu, svrha vaza bila je "da pojačaju i poljepšaju zvuk". Danas se zna da su rezonatori bili postavljeni da bi proizvodili umjetni odjek $(0,5-2 \mathrm{~s})$.

Panelni rezonatori grade se najčešće tako da se čvrsta tanka panelna ploča s izbušenim okruglim ili duguljastim rupama učvrsti na stanovitoj udaljenosti od zida (slika 19). Ako su rupe okrugle, obično im je promjer 3-5 $\mathrm{mm}$, a međusobni razmak 10-15 mm.

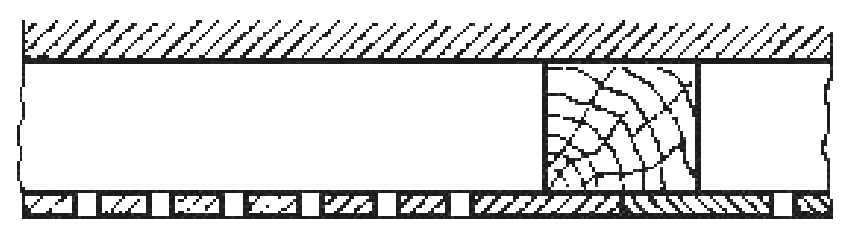

Slika 19 - Presjek panelnog akustičnog rezonatora ${ }^{21}$

\section{Zaključak}

Čovjek danas živi u izrazito bučnom svijetu. Izloženi smo zvuku koji ne želimo, kojeg ne trebamo, skoro 24 sata dnevno, a sve to zahvaljujući sve intenzivnijem razvoju tehnologije i industrije. Povećan cestovni, a posebice zračni promet, ugrožava sve veći broj ljudi. Naši domovi više nisu mirna utočišta kakva bi trebala biti, radna mjesta su zbog buke sve manje produktivna, a školske ustanove sve teže uspijevaju osigurati kvalitetan proces učenja i obrazovanja. Činjenica da buka nije samo smetnja nego i prijetnja zdravlju, navela je mnoge zemlje da

21 Jelaković T.: Zvuk, sluh, arhitektonska akustika. Školska knjiga, Zagreb, 1978. str. 195. 
se ozbiljnije pozabave ovim pitanjem. Tako su doneseni mnogi standardi i zakoni kojima se nastoji regulirati razinu buke u čovjekovu okruženju. Međutim, ti standardi ne pružaju onakvu razinu akustičke udobnosti kakvu mogu pružiti suvremena tehnička rješenja.

Razni izolacijski sustavi i proizvodi koji danas postoje daju temelj za dobra građevinska rješenja zaštite od buke, a samim time pridonose kvaliteti življenja. No tu se ne smije stati. Potreban je daljnji razvoj i daljnja istraživanja kako bi se došlo do novih, kvalitetnijih, jeftinijih i najvažnije po okoliš, zdravih materijala koji će omogućiti stvaranje akustički ugodnog, funkciji primjerenog i zdravog okruženja u zgradama.

\section{$6 \quad$ Literatura}

1. Jelaković, T.: Zvuk, sluh, arhitektonska akustika, Školska knjiga, Zagreb, 1978.

2. Mijić, M.: Akustika u arhitekturi, Nauka, Beograd, 2001.

3. Bilan, O.: Akustika prostorija, Split, 1998.

4. Šimetin, V.: Građevinska fizika, GI Fakultet građevinskih znanosti, Zagreb,1983.

5. Zvuk i akustika, Drvo znanja, br. 61(2003.), str 15-18.

6. Zvuk, Drvo znanja, br. 122(2009.), str. 32-37.

7. http://www.isover.hr/ltem.aspx?ld=21

8. http://www.isover.hr/ltem.aspx?ld=42

9. http://www.isover.hr/ltem.aspx?ld=43

10. http://hr.wikipedia.org/wiki/Zvuk 